\title{
Ectopic Expression of Xylella fastidiosa rpfF Conferring Production of Diffusible Signal Factor in Transgenic Tobacco and Citrus Alters Pathogen Behavior and Reduces Disease Severity
}

\author{
R. Caserta, ${ }^{1}$ R. R. Souza-Neto, ${ }^{1,2}$ M. A. Takita, ${ }^{1}$ S. E. Lindow, ${ }^{3}$ and A. A. De Souza, ${ }^{1,+}$ \\ ${ }^{1}$ Centro de Citricultura Sylvio Moreira/IAC, Corderiópolis, SP, Brazil; ${ }^{2}$ Universidade Estadual de Campinas-UNICAMP, \\ Campinas, SP, Brazil; and ${ }^{3}$ University of California, Berkeley, CA, U.S.A.
}

Accepted 31 July 2017.

\begin{abstract}
The pathogenicity of Xylella fastidiosa is associated with its ability to colonize the xylem of host plants. Expression of genes contributing to xylem colonization are suppressed, while those necessary for insect vector acquisition are increased with increasing concentrations of diffusible signal factor (DSF), whose production is dependent on RpfF. We previously demonstrated that transgenic citrus plants ectopically expressing $r p f F$ from a citrus strain of $X$. fastidiosa subsp. pauca exhibited less susceptibility to Xanthomonas citri subsp. citri, another pathogen whose virulence is modulated by DSF accumulation. Here, we demonstrate that ectopic expression of $r p f F$ in both transgenic tobacco and sweet orange also confers a reduction in disease severity incited by $X$. fastidios $a$ and reduces its colonization of those plants. Decreased disease severity in the transgenic plants was generally associated with increased expression of genes conferring adhesiveness to the pathogen and decreased expression of genes necessary for active motility, accounting for the reduced population sizes achieved in the plants, apparently by limiting pathogen dispersal through the plant. Plant-derived DSF signal molecules in a host plant can, therefore, be exploited to interfere with more than one pathogen whose virulence is controlled by DSF signaling.
\end{abstract}

The plant-pathogenic bacterium Xylella fastidiosa is limited to xylem vessels in plant hosts and causes serious economic losses to several important crops, such as grapevines, almonds, and citrus (Hopkins and Purcell 2002; Machado et al. 1994) and has recently spread to olive trees in Italy (Saponari et al. 2013). In plant hosts, $X$. fastidiosa is able to switch between two lifestyles: an exploratory behavior in which bacteria having apparently low adhesiveness move along and between xylem vessels and an adhesive form that, while limited in its ability to move within plants, can be more efficiently acquired by insect vectors (Chatterjee et al. 2008). The partitioning of the population into cells having these two opposite behaviors is regulated by their exposure to different concentrations of diffusible signal factor (DSF), whose production is conferred by an

${ }^{\dagger}$ Corresponding author: A. A. De Souza;

E-mail: desouza@ccsm.br

*The $\boldsymbol{e}$-Xtra logo stands for "electronic extra" and indicates that one supplementary figure and two supplementary tables are published online.

@ 2017 The American Phytopathological Society enzyme encoded by rpfF (Newman et al. 2004). RpfF has both thioesterase and dehydratase activities and is also required for the perception of this molecule (Ionescu et al. 2013). The expression of a wide range of genes is dependent on DSF in $X$. fastidiosa, clearly demonstrating its role in behavior (Wang et al. 2012). While DSF production is considered an antivirulence factor in $X$. fastidiosa, due to the hypervirulent phenotype exhibited by cells impaired in DSF production (Newman et al. 2004), its production is necessary for virulence of Xanthomonas citri subsp. citri (Guo et al. 2012). Thus, while similar unsaturated fatty acid signal molecules and similar signal transduction systems are involved in regulating virulence of these different plant pathogens, the virulence phenotypes achieved upon detecting DSF and, thus, entering a "quorum state" are quite distinct.

Recently Lindow et al. (2014) demonstrated the possibility of achieving disease control by a process of "pathogen confusion," whereby ectopic expression of pathogen genes required for DSF production led to altered concentration of this pathogen signal molecule in plants. Transgenic grapevines expressing rpfF from the $X$. fastidiosa subsp. fastidiosa Temecula strain exhibited high levels of disease resistance that was associated with reduced pathogen movement and multiplication within xylem vessels (Lindow et al. 2014). Moreover, in a previous work, we demonstrated that citrus plants in which the rpfF gene from $X$. fastidiosa subsp. pauca 9a5c (Simpson et al. 2000) was expressed were capable of producing DSF-like signal molecules and exhibited considerable resistance to Xanthomonas citri subsp. citri (Caserta et al. 2014). Various virulence genes in this pathogen were expressed at lower levels in the transgenic plants than in wild-type plants, apparently due to antagonism of DSF-based signal transduction by the heterologous DSF-like molecules produced in this transgenic rpfF-expressing host. Until now, however, it has not been possible to determine the susceptibility of the $r p f F$-expressing citrus plants to infection by $X$. fastidiosa because of the long time needed for symptom development in this pathosystem. While DSF-like signal molecules can apparently be made in transgenic rpfF-expressing citrus plants, it was important to determine whether the DSF molecular species produced in citrus included those that could be perceived by $X$. fastidiosa, because of the apparent promiscuity in the DSF synthase seen in grape strains of this pathogen (Ionescu et al. 2016). Likewise, achieving pathogen confusion for the control of citrus variegated chlorosis (CVC) is dependent on the production of sufficient amounts of suitable DSF signal molecules in transgenic plants. Therefore, new transgenic lines of Hamlin sweet orange in which $X$. fastidiosa $r p f F$ was expressed 
were obtained in the present work and were challenged with $X$. fastidiosa, together with the transgenic Pineapple orange lines previously described (Caserta et al. 2014). Ectopic expression of $r p f F$ was also assessed in the model plant tobacco to further verify the host-independence of the strategy of pathogen confusion. We show, here, that the transformed plants displayed a reduction in severity of symptoms upon inoculation with $X$. fastidiosa that was associated with reduced bacterial colonization of xylem vessels. We show that the strategy of pathogen confusion can be used to simultaneously control diseases conferred by different pathogens that share a common cell densitydependent signal transduction system.

\section{RESULTS}

Tobacco and citrus plants transformed with $r p f F$ from a citrus strain of $X$. fastidiosa.

The transformation of tobacco resulted in 148 regenerated plants, 24 of which were confirmed, using polymerase chain reaction (PCR) to amplify the transgene (Supplementary Table $\mathrm{S} 1)$. The transformation efficiency for citrus differed by variety. For Hamlin and Pineapple sweet orange lines, the transformation efficiencies were 20.77 and $14.45 \%$ respectively. Interestingly, the number of $\beta$-glucuronidase (GUS)-positive plants of both plant species was higher than the number of plants for which the presence of $r p f F$ could be confirmed by PCR. While 42 tobacco plants exhibited GUS activity, rpfF was confirmed in only 24 . Similarly, in citrus, approximately 30 plants were GUS-positive while only 15 harbored $r p f F$. The absence of $r p f F$ in GUS-positive shoots is probably due to deletions of T-DNA regions during its insertion in the host DNA. The integration of the T-DNA depends on the DNA repair machinery from the host genome (Bourras et al. 2015) and happens through a mechanism of illegitimate recombination that begins at the site of the double-strand break in the plant chromosome (Gelvin 2010). This process may cause a disruption in the T-DNA during integration resulting in T-DNA truncated sequences (Krysan et al. 2002; Radhamony et al. 2005). This reinforces the need for verification of the transgene presence in addition to scoring only for the marker gene.

Ten transgenic tobacco lines were initially challenged with $X$. fastidiosa to reveal the five having the highest resistance to $X$. fastidiosa (data not shown). These five lines were then further evaluated. The expression of $r p f F$, evaluated by quantitative reverse transcription (qRT)-PCR, varied modestly among these lines (Fig. 1A). For transgenic citrus plants, rpfF expression, which varied substantially between lines, was confirmed in all transgenic lines evaluated (Fig. 1B).

Since the transgene expression varied among the transgenic citrus plants, we evaluated the copy number of $r p f F$ in each transgenic line. All the transgenic lines presented only one copy of the transgene (Supplementary Table S2); thus, the variation in $r p f F$ expression among the lines is probably related to the position of its insertion in the host genome, which can influence the expression of the transgene (Schnell et al. 2015).

\section{Transgenic tobacco plants expressing rpfF exhibit fewer disease symptoms and reduced colonization by $X$. fastidiosa.}

Both wild-type and transgenic tobacco lines inoculated with $X$. fastidiosa exhibited initial disease symptoms by three months after inoculation. Symptoms of $X$. fastidiosa infection in tobacco included necrotic spots that initially appeared around the edge of the leaf, conferring leaf scorch symptoms, but that subsequently spread throughout the whole leaf, typical symptoms of $X$. fastidiosa in tobacco (Lopes et al. 2000) (Fig. 2C). The transgenic plants exhibited less severe symptoms than the wild-type plants (Fig. 2C).
Higher numbers of scorched or dead leaves close to the point of inoculation were seen in wild-type plants than in the transgenic lines (Fig. 2C). In general, transgenic plants showed a healthier appearance, exhibiting no water stress, and with leaves having a higher turgor than that of wild-type plants (Fig. 2C).

In order to determine whether increased disease resistance was fully heritable, plants derived from seeds from self-crosses of the transgenic lines were again inoculated with the pathogen. The reduced susceptibility originally seen in these lines was also observed in their progeny. Typically, mild disease symptoms that appeared at the margins of the leaves did not evolve to include the whole leaf. Disease incidence was assessed in the original transformed plants and $\mathrm{T} 1$ and $\mathrm{T} 2$ generations, while severity was assessed only in T2 plants. The incidence of symptoms was significantly lower in four transgenic lines compared with the wild-type plants (Fig. 2A). While symptoms were seen in about $90 \%$ of wild-type leaves, disease incidence in transgenic lines Nt_rpfF-2, Nt_rpfF-4, and Nt_rpfF-5 was only about $60 \%$ and was even lower in line Nt_rpfF-3 (Fig. 2A). For severity, the results were more uniform, with all the transgenic lines showing significant reduction of disease severity compared with wild-type plants (Fig. 2B).

Since symptoms caused by $X$. fastidiosa in host plants are dependent on successful bacterial movement along and between xylem vessels, we evaluated the spatial patterns of pathogen colonization of wild-type and transgenic tobacco plants to determine whether the reduced disease susceptibility of transgenic plants could be ascribed to changes in pathogen behavior. The population size of $X$. fastidiosa in transgenic plants at a given point distal to the point of inoculation was always less than that in the wild-type plants (Fig. 3A). While in general, pathogen populations in transgenic plants averaged about 10 -fold less than that in wild-type plants, population differences were often
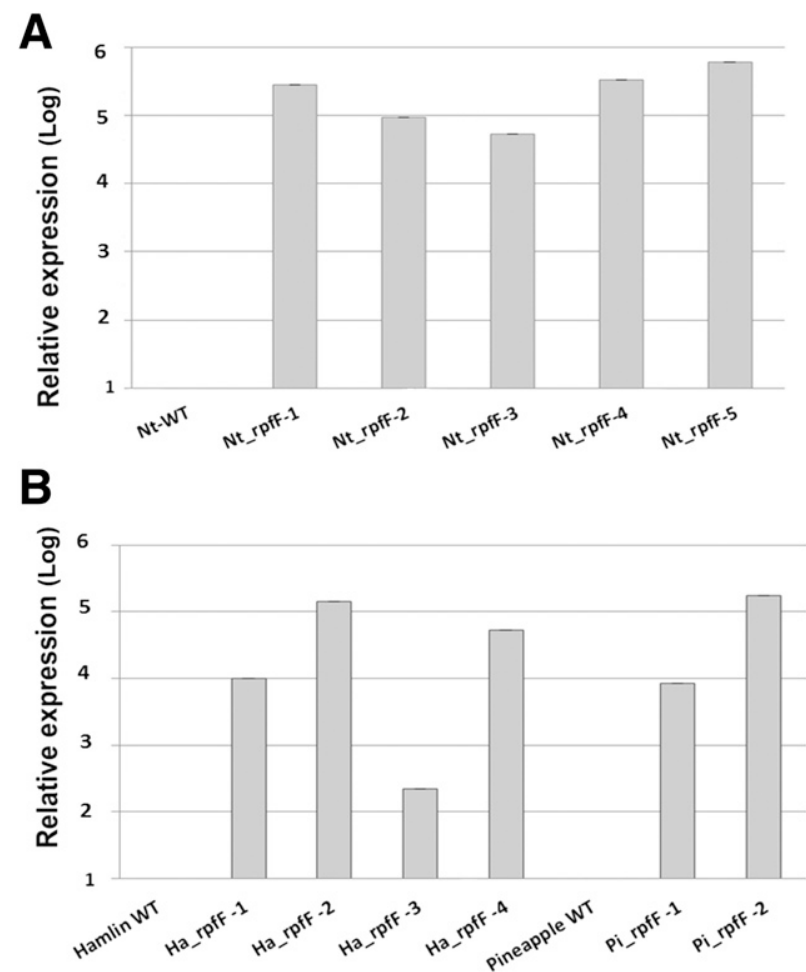

Fig. 1. Relative expression of $r p f F$ in the transgenic lines. A, Expression of $r p f F$ in transgenic Nicotiana tabacum (Nt) lines. Relative expression was quantified in relation to that of the NtArpc3 gene as endogenous control. B, Expression of $r p f F$ in transgenic citrus events. Expression was quantified in relation to the cyclophylin gene as endogenous control. Ha = transgenic Hamlin lines and $\mathrm{Pi}=$ Pineapple. Error bars represent standard deviation of the means. 
greatest at the most distal sampling sites (Fig. 3A). While the percentage of vessels that were colonized by $X$. fastidiosa was not assessed, these results suggest that bacterial movement both along and, particularly, between xylem vessels was compromised, resulting in fewer vessels at a given location harboring the pathogen.

\section{Transgenic sweet orange plants harboring $r p f F$ exhibit decreased severity of CVC.}

Individual transgenic lines of different orange varieties verified to be nonchimeric for the presence of $r p f F$ were inoculated with $X$. fastidiosa to evaluate their susceptibility to disease. The GUS assay of all grafted, transformed plants was assessed prior to $X$. fastidiosa inoculation to avoid the use of chimeric plants. A total of 11 of 48 selected transgenic Hamlin plants from four events (Ha_rpfF-1 to Ha_rpfF-4) were GUS-negative after grafting, suggesting the presence of chimeras in some lines. Thus, only plants both expressing GUS and for which the presence of $r p f F$ could be confirmed by PCR were used for further experiments. In contrast to that seen in Hamlin transgenic plants, all grafted plants from two transgenic Pineapple orange lines (Pi_rpfF-1 and Pi_rpfF-2) both expressed GUS and harbored $r p f F$, indicating that the original transformants were not chimeric (data not shown). Thirty days after $X$. fastidiosa inoculation, diagnostic PCR detected the pathogen in about $60 \%$ of the inoculated plants, and only these plants that had been successfully inoculated were used in further experiments (at least five plants for each line).

The first CVC symptoms were observed seven months after inoculation, in both wild-type and transgenic plants, but the majority of the plants showed symptoms only after nine months following inoculation (data not shown). Thus, the initial assessment of incidence and severity of CVC symptoms in wildtype and transgenic plants was done after nine months, with a subsequent evaluation 18 months after inoculation. These sampling times were chosen to represent the initial and advanced stages of CVC symptoms, respectively. The incidence of CVC symptoms in transgenic Hamlin and Pineapple plants was significantly

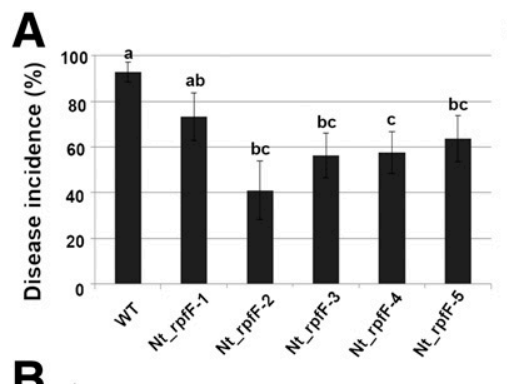

B

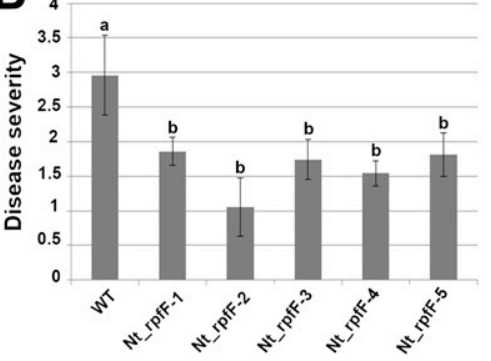

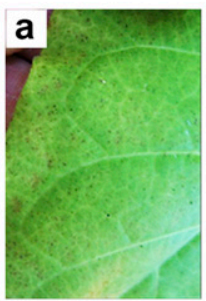
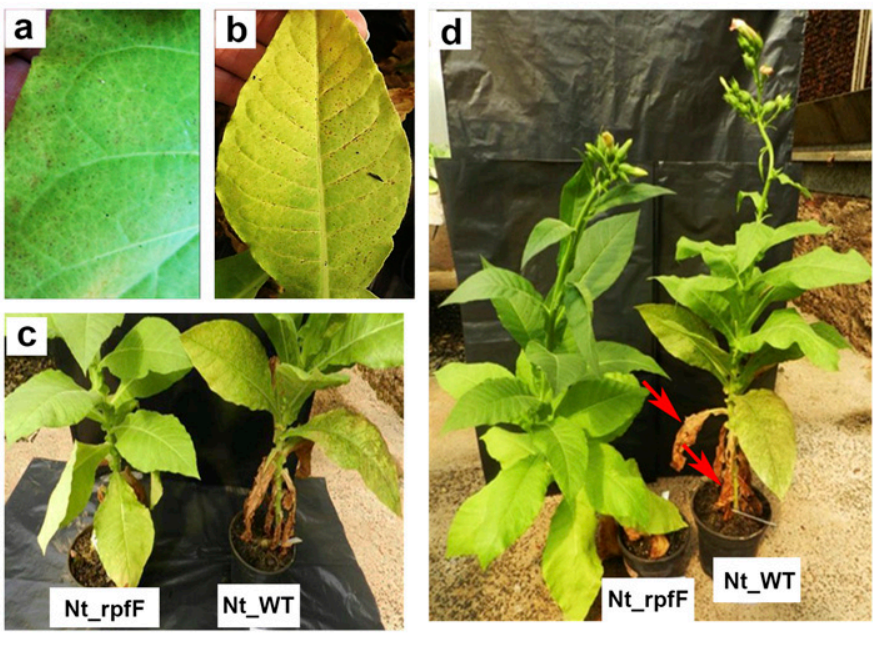

Fig. 2. Incidence and severity of symptoms caused by Xylella fastidiosa infection in transgenic tobacco lines. Fifteen seedlings from transgenic lines Nt_rpfF-1, $\mathrm{Nt} \_r p f F-2, \mathrm{Nt} \_r p f F-3, \mathrm{Nt} \_r p f F-4$, and Nt_rpfF-5 were evaluated by three different evaluators. A, Incidence of symptomatic leaves in transgenic and wild-type (WT) plants. B, Severity scores of transgenic and WT plants. Different letters indicate significant differences for incidence and severity as analyzed by one-way analysis of variance followed by $t$ test $(P<0.05)$. Error bars represent standard errors of the means. C, Differences in symptoms of transgenic and WT tobacco plants after inoculation with $X$. fastidiosa: a, necrotic spots around the edge of the leaf are characteristics of initial symptoms of $X$. fastidiosa infection; $b$, later symptoms showing necrotic spots all over the leaf; c, higher numbers of dead leaves close to the point of inoculation in WT plants (red arrows); d, differences in overall appearance of transgenic $\left(\mathrm{Nt}_{-} r p f F\right)$ and WT tobacco plants, both displaying symptoms.
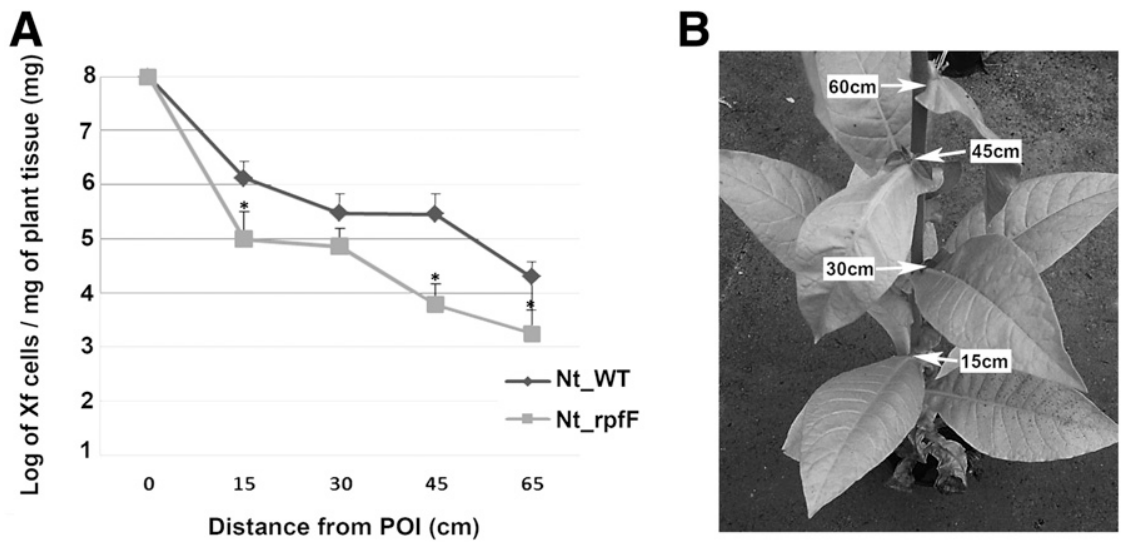

Fig. 3. Xylella fastidiosa population size determined in petioles collected at various distances from the point of inoculation by quantitative polymerase chain reaction in wild-type (WT) and transgenic tobacco plants. A, Number of bacterial cells in WT and transgenic (Nt_rpfF) petioles. B, Illustration of the sites at which plants were sampled $15,30,45$, and $65 \mathrm{~cm}$ from the inoculation point. Error bars represent standard error of the means. 
lower than that in control plants, when assessed nine months after inoculation but not later in the infection process, when most plants had exhibited symptoms (Fig. 4A). However, when the incidence of symptom development was considered among the many replicate plants for a given transgenic line, line Ha_rpfF-4 exhibited a significantly lower incidence of CVC compared with the control plants, at both nine $(P=0.014)$ and $18(P=0.011)$ months after inoculation.

The severity of symptoms was evaluated at these same stages of disease progression, using a previously developed diagrammatic scale (Amorin et al. 1993; Muranaka et al. 2013). Whereas the severity of CVC leaf symptoms in transgenic lines was significantly lower than that of wild-type plants when assessed 18 months after inoculation for both orange varieties, the lower disease severity seen after nine months of incubation was not significant (Fig. 4B). While wild-type Hamlin orange exhibited higher disease severity than that of wild-type Pineapple orange, it is noteworthy that a similar proportional decrease in disease severity was conferred by expression of RpfF in these two orange varieties (Fig. 4B). Transgenic Hamlin line Ha_rpfF-4 had the lowest disease severity at nin months, differing from that of control plants $(P=$ 0.048). As was seen with disease incidence, transgenic Pineapple line Pi_rpfF-2, exhibited significantly lower disease severity than control plants when assessed at nine months $(P=0.028)$.

Since disease severity was assessed at multiple time points, we calculated the area under the disease-progress curve (AUDPC) to assess the overall effect of the transgenic trait on disease progress. Expression of $r p f F$ in the transgenic orange varieties conferred a significant reduction in progression of severity of 28.1 and $31 \%$ for Hamlin and Pineapple, respectively, compared with wild type (Fig. 4C). The progressive decrease seen in CVC disease severity in rpfF-expressing plants over time is illustrated in Figure 5.

\section{Citrus expressing RpfF reduce}

\section{$X$. fastidiosa colonization and alter bacterial behavior.}

To investigate how RpfF affects bacterial colonization in citrus, we compared $X$. fastidiosa population sizes in petioles at different distances from the point of inoculation in transgenic lines and wild-type plants. The population size of $X$. fastidiosa cells was almost always higher in wild-type plants than in transgenic plants at sites distal from the point of inoculation (Fig. 6). In both transgenic Hamlin and Pineapple sweet orange, the difference in population size between transgenic and wildtype plants increased with increasing distance from the point of inoculation. For example, population sizes in transgenic Hamlin lines were 10-fold lower than in the wild type when measured $60 \mathrm{~cm}$ in the point of inoculation but greater than 100 fold lower at $120 \mathrm{~cm}$ (Fig. 6A). The progressive increase in the difference between population sizes of the pathogen with distance, which is also associated with increasing time after inoculation, probably contributed to the observations that expression of $r p f F$ in transgenic plants conferred the greatest reduction of disease severity at later evaluation times (Fig. 4).

To more directly link RpfF function in transgenic plants with a direct effect on bacterial behavior leading to reduced virulence of $X$. fastidiosa, we assessed the expression of genes considered to encode both virulence as well as antivirulence factors in the pathogen by qRT-PCR analyses. Genes contributing to adhesiveness and biofilm formation ( $x a d A 1$, fimA, hsf, and gumB) were up-regulated in $X$. fastidiosa cells isolated from both transgenic Hamlin and Pineapple sweet orange plants (Fig. 7). In contrast, genes required for active movement ( $p i l S$ and pilP) were down-regulated in $X$. fastidiosa isolated from transgenic Hamlin plants but not modulated in cells isolated from transgenic Pineapple sweet orange (Fig. 7). Curiously $h x f B$, which is known to be upregulated in the presence of exogenous DSF in grape strains of $X$. fastidiosa (Wang et al. 2012), was downregulated in the citrus strain of $X$. fastidiosa used in the study when isolated from plants harboring $r p f F$. Taken together, the results suggest that, in transgenic rpfF plants, $X$. fastidiosa is probably more adhesive and exhibits lower active motility, both contributing to reduced movement within the xylem vessels.
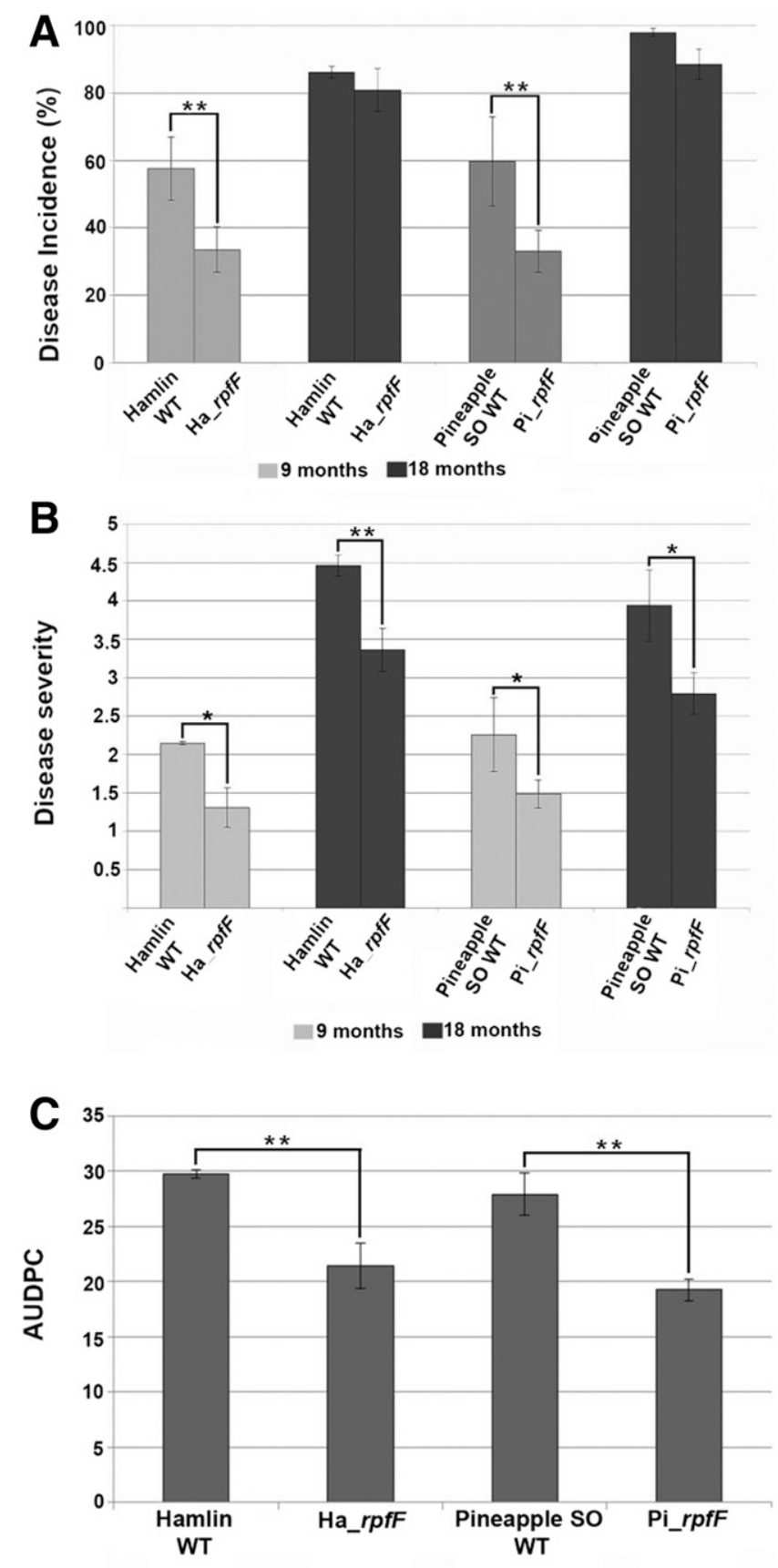

Fig. 4. Citrus variegated chlorosis (CVC) symptoms in wild type (WT) and $r p f F$-expressing transgenic orange varieties. A, Average incidence and $\mathbf{B}$, severity of CVC symptoms in transgenic and WT citrus plants. Seven plants from each of four transgenic lines of Hamlin, Ha_rpfF, and two transgenic lines of Pineapple sweet orange, and Pi_rpfF were evaluated by three different evaluators at 9 and 18 months. C, Area under the disease progress curve (AUDPC) for severity of CVC symptoms in Hamlin and Pineapple WT and transgenic lines. Average of CVC scores at 9 and 18 months were used to calculate the disease progression curve. Vertical lines refer to the standard error of the mean. Asterisks show statistically significant differences analyzed by one-way analysis of variance followed by $t$-test (one asterisk [*] indicates $P<0.05$ and two $[* *] P<0.01)$. Error bars represent standard error of the means. 


\section{DISCUSSION}

The fact that cell-density control of gene expression, commonly known as quorum sensing (Kaplan and Greenberg 1985), frequently controlled a large variety of genes, often including virulence genes, in pathogenic bacterial species has stimulated interest in strategies by which disease can be blocked by altering the signal transduction process (Helman and Chernin 2015). Several such strategies for altering gene expression in bacterial pathogens in a way that would either reduce their virulence or increase the resistance of plants have been investigated. For example, expression of a $N$-acyl homoserine lactonase to prevent the accumulation of $\mathrm{N}$-acyl homoserine lactones (AHLs) that positively regulate virulence factors, such as extracellular enzymes, produced by the pathogen that are necessary for disease can inhibit the disease process (Park et al. 2005). Conversely, production of AHLs in plants by ectopic expression of biosynthetic genes from the pathogen can also lead to enhanced disease resistance, apparently by prematurely causing the expression of effectors in the pathogen early in the infection process, enabling the plant to detect the pathogen and, thus, mount a robust defense response before the pathogen has inflicted damage to the plant (Schenk et al. 2014; Schikora et al. 2011). X. fastidiosa is rather unique among pathogenic bacteria in that its quorum sensing signal, DSF, consisting of a family of related 2-enoic fatty acids (Beaulieu et al. 2013), function to stimulate the expression of genes that are considered antivirulence factors (Guilhabert and Kirkpatrick 2005; Wang et al. 2012). Blockage of expression of $X$. fastidiosa virulence genes was, therefore, deemed possible if DSF could be produced in plants. Transgenic grapevine ectopically expressing the DSF synthase RpfF from a grape strain of $X$. fastidiosa produced a variety of 2-enoic acids, including those having DSF signaling activity that reduce the growth and movement of $X$. fastidiosa after infection (Lindow et al. 2014). The reduced virulence of $X$. fastidiosa in these transgenic plants could be attributed to its increased adhesiveness in the plants in which a variety of
DSF-like enoic acids could be detected (Lindow et al. 2014). Surprisingly, a variety of 2 -enoic acids could be detected in transgenic grape harboring $r p f F$, some of which are not produced by the $X$. fastidiosa $\mathrm{RpfF}$ source strain (Lindow et al. 2014). $X$. fastidiosa RpfF has now been shown to be a rather flexible DSF synthase, producing a variety of different 2-enoic acids with DSF signaling activity, depending on environmental conditions that alter the relative abundance of precursor molecules (Ionescu et al. 2016). Furthermore, apparently unlike most other bacteria using DSF signal molecules, $X$. fastidiosa is rather promiscuous, responding to 2-enoic acids with a rather wide range of chain lengths and even the position of unsaturation in the molecule (Ionescu et al. 2016). It could, therefore, be expected that different plant species harboring RpfF could produce differing DSF-like molecules and that a pathogen confusion disease control strategy based on plant production of DSF could be context-dependent. The results of this study show that, like in grape, expression of $r p f F$ in both tobacco and citrus varieties apparently altered the behavior of the citrus strain of $X$. fastidiosa. While the DSF-based quorum sensing system in CVC strains of $X$. fastidiosa has not been well-studied, the high genomic similarity between $X$. fastidiosa strains and conservation of the $r p f$ genes (Van Sluys et al. 2003) suggest that it functions similarly as in grape strains of the pathogen that have been studied in more detail. The reduced expression of genes involved in active motility as well as increased expression of a variety of genes conferring adhesiveness to $X$. fastidiosa in cells recovered from $r p f F$-expressing citrus (Fig. 7) suggest strongly that it had responded to DSF-like molecules in the transgenic plants in a manner similar to that seen for grape strains of the pathogen within transgenic rpfF grape (Lindow et al. 2014). Thus, even though it might be expected that different transgenic RpfF plant species might produce different families of 2-enoic acids, the promiscuous perception of a relatively wide variety of 2-enoic acids by $X$. fastidiosa would likely ensure success of such a strategy of control of diseases caused by this pathogen in the wide variety of its host plant species.
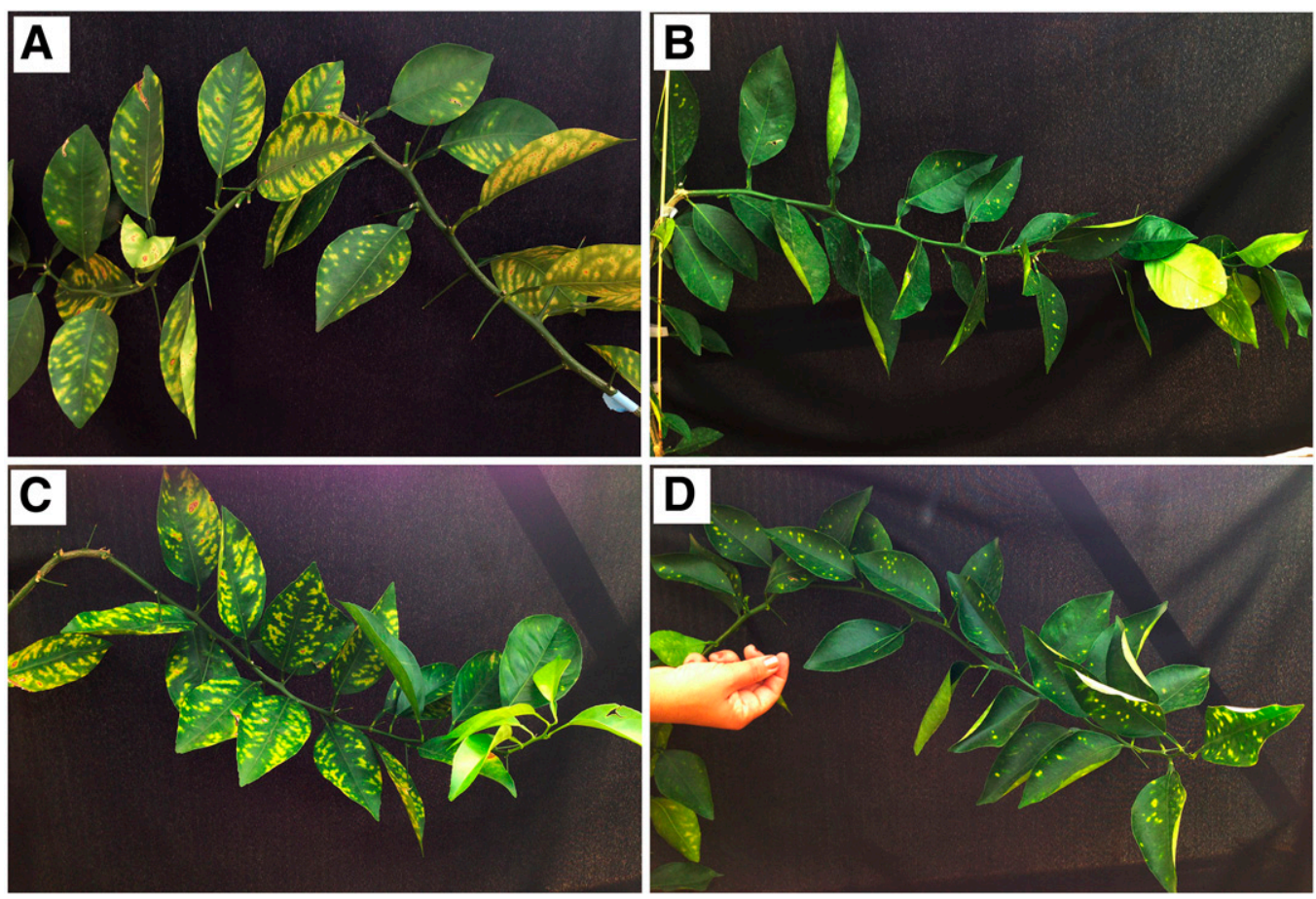

Fig. 5. Incidence and severity of citrus variegation chlorosis leaf symptoms in transgenic Hamlin and Pineapple orange and wild-type plants 18 months after inoculation with Xylella fastidiosa. A, Wild-type Hamlin plant. B, Representative transgenic Hamlin line. C, Wild-type Pineapple sweet orange plant. D, Representative transgenic Pineapple line. 
As seen in transgenic $r p f F$ grape, DSF production in both tobacco and citrus did not prevent infection of the plant following inoculation but, instead, reduced the rate of disease development (Figs. 2 and 4). This was particularly obvious in the case of citrus, where the incidence of plants showing any symptoms was substantially lower in $r p f F$-transformed plants compared with the wild-type strain only early in the infection process (Fig. 4). Eventually, however, nearly all plants showed at least some evidence of infection by X. fastidiosa (Fig. 4). More importantly, however, the severity of disease symptoms was always lower in $r p f F$-transformed citrus and the magnitude of the difference increased with time after inoculation (Fig. 4). Such observations were consistent with the differences in population size of the pathogen in the plant which, while nearly always lower in $r p f F$-transformed citrus, became a progressively smaller fraction of that seen in wild-type plants with time after inoculation (Fig. 6). Such observations are consistent with a model in which the efficiency with which a given cell of the pathogen in a DSF-producing plant can move from one xylem vessel to another where it could then proliferate is lower than in a normal plant. Over time, the fraction of xylem vessels in a plant that would become colonized by the pathogen would increase at a much lower rate, with the difference in the proportion of vessels colonized increasing with time after infection. While the mechanisms by which $X$. fastidiosa causes disease symptoms in plants remains unclear, it is very likely that symptom development is proportional to the fraction of vessels that become colonized by the pathogen.
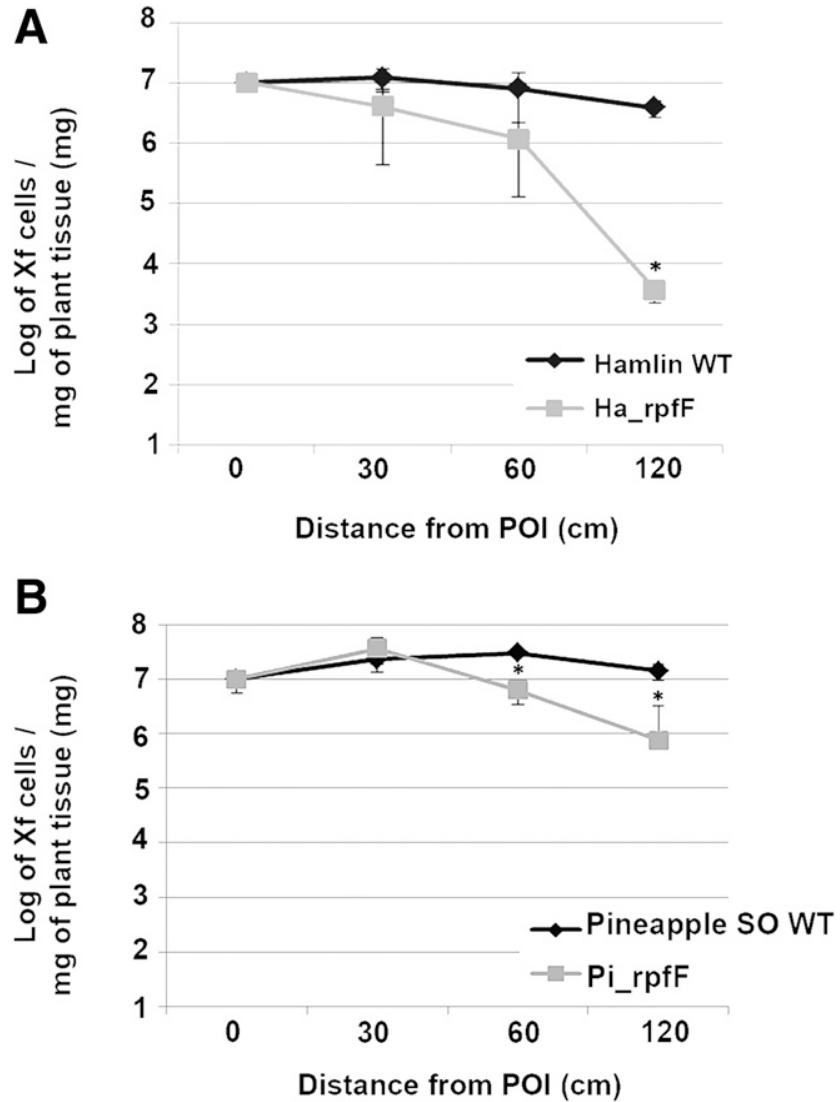

Fig. 6. Xylella fastidiosa population size determined in petioles collected at various distances from the point of inoculation by quantitative polymerase chain reaction in wild-type (WT) and transgenic sweet orange plants. A, Hamlin transgenic (Ha_rpfF) and WTplants. B, Pineapple sweet orange transgenic $(\mathrm{Pi}$ rpfF $)$ and WT plants. Error bars represent standard error of the means. Asterisks indicate significant difference $(P<0.05)$ between the mean values of bacterial population in transgenic and WT plants.
For the $X$. fastidiosa citrus strain, it was recently shown that overexpression of the MqsR toxin results in upregulation of genes related to adhesins and downregulation of genes associated with active movement, leading to loss of virulence in the citrus host (Merfa et al. 2016), thus reinforcing that systemic bacterial colonization is essential for disease symptom development. In addition, in grape, it has been suggested that the induction of tyloses is triggered by perception of the pathogen in a given vessel and that the spread of the pathogen throughout the vascular system thereby induces such blockages in the vessels, contributing to symptom development (Sun et al. 2013). Thus, while the control of diseases caused by $X$. fastidiosa by introducing DSF production into a plant species is unlikely to be complete, it would be expected that disease would always progress more slowly within plants after infection. In field conditions, citrus trees with severe CVC symptoms have a reduced fruit size, which makes them inappropriate for the juice market. Therefore, the results with $r p f F$-transformed citrus are very promising, since the much slower rate of disease progression would maintain the productivity of these plants. Field trials will be done to test this hypothesis.

The reduced susceptibility of citrus varieties harboring rpfF to both $X$. fastidiosa and Xanathomonas citri appears to be due to a fortuitous feature of the related but different DSF-based quorum sensing systems that these pathogens share. The upregulation in the expression of $X$. fastidiosa antivirulence genes responsive to DFS suggests that the molecules produced by transgenic plants serve as an agonist to the DSF signaling system.

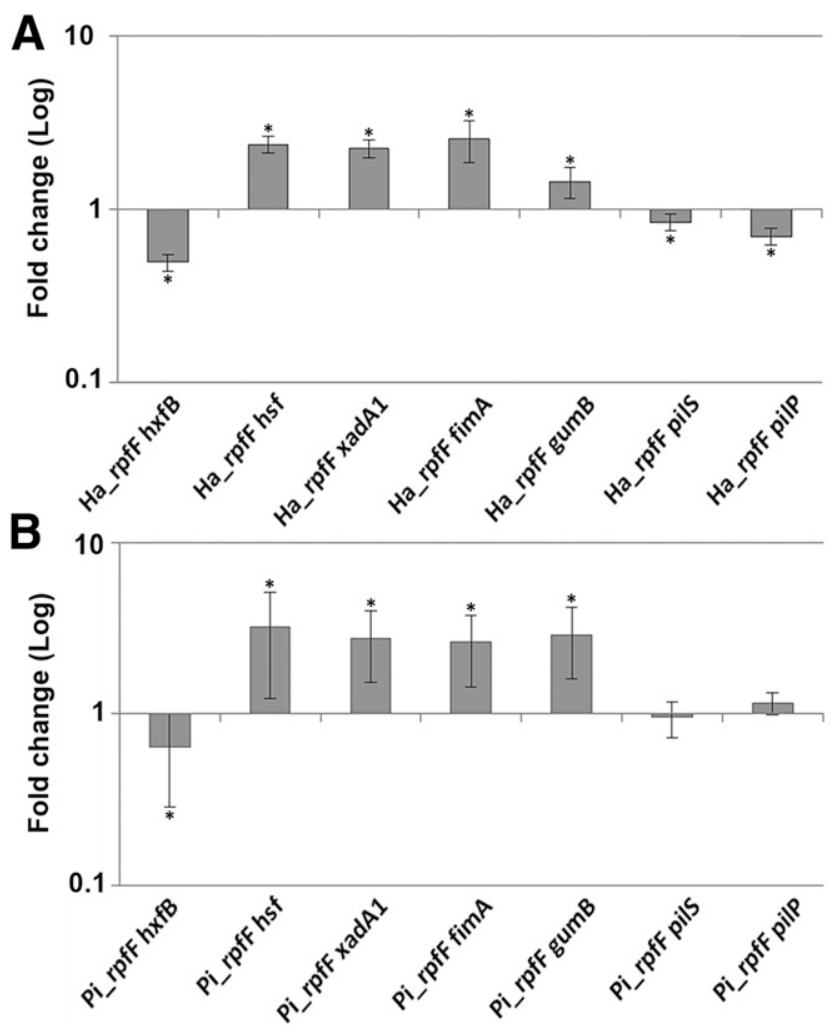

Fig. 7. Relative expression of diffusible signal factor-responsive genes in Xylella fastidiosa. A, Bacterial cells isolated from transgenic Hamlin orange. B, Bacterial cells isolated from transgenic Pineapple sweet orange. Shown is the ratio of expression of a given gene in the transgenic plant compared with that of the wild-type plant. Results are mean of three independent experiments. Vertical lines indicate the standard deviation of the means. Asterisks indicate significant differences $(P<0.05)$ between the mean ratios for a given gene. Error bars represent standard deviation of the means. 
In contrast, in $r p f F$-transformed sweet orange plants, the DSF-like compounds served as antagonists to DSF-signaling Xanathomonas citri (Caserta et al. 2014). We previously demonstrated DSF production in transgenic citrus plants (Caserta et al. 2014). While compounds were detected in xylem sap from $r p f F$-transformed citrus plants that could induce expression of an $h x f A$-based DSF biosensor in a grape strain of $X$. fastidiosa, xylem sap from these plants reduced expression of genes known to be induced by DSF in Xanathomonas citri (Caserta et al. 2014). While the most effective DSF signaling molecules for both $X$. fastidiosa and Xanthomonas species are 2-enoic acids, X. campestris pv. campestris, and probably Xanathomonas citri, respond almost exclusively to 12and 13-carbon 2-enoic acids, while $X$. fastidiosa, although capable of responding to 12-carbon enoic acids, responds maximally to 16to 18-carbon enoic acids (Ionescu et al. 2016). Responsiveness to its cognate DSF can be blocked by certain other enoic acids with saturations other than at the number 2 carbon and by some other saturated fatty acids in X. fastidiosa (Ionescu et al. 2016). Such antagonism has not been examined in Xanthomonas species but would not be unanticipated. Apparently, transgenic citrus species harboring RpfF produced one or more such molecules that interfered with DSF signaling in Xanathomonas citri but not in $X$. fastidiosa. Such an outcome has had the highly beneficial result of simultaneously reducing the susceptibility of $r p f F$-transformed citrus varieties to two very different but highly destructive pathogens. A more complete assessment of the various fatty acids and related molecules produced in $r p f F$-transformed citrus should help in both understanding the mechanism by which simultaneous disease suppression has been achieved as well as to perhaps better direct the production of appropriate compounds maximizing control of both pathogens in future work. In addition, the results shown here demonstrate possibilities for using the DSF augmentation strategy to confer broad-spectrum disease resistance, since $X$. fastidiosa and Xanthomonas spp. are pathogens of a wide range of plant species of economic importance.

While changes in expression of DSF-responsive genes in both $X$. fastidiosa and Xanathomonas citri in rpfF-expressing citrus support a model of disease control due to direct effects on expression of virulence and antivirulence genes in these pathogens, it is possible that there could have been an effect of DSF on the plant itself. DSF has been shown to elicit innate immunity in plants in which many different defense responses were observed, such as induction of reactive oxygen species and the PATHOGENESIS-RELATEDl gene (Kakkar et al. 2015). While there is little evidence of active defense mechanisms in diseases caused by $X$. fastidiosa, we cannot discard the possibility that the molecules produced by the transgenic citrus plants could be perceived by themselves, priming the plants for defense responses against both pathogens.

\section{MATERIALS AND METHODS}

Construction of the binary vector, plant transformation, and selection.

The binary vector pCambia2301 containing the target gene rpfF from $X$. fastidiosa 9a5c was produced as described by Caserta et al. (2014). This construction, rpfFpCambia2301, was used to transform both citrus and tobacco. Citrus was transformed as previously detailed (Caserta et al. 2014) and leaf disks of tobacco were used as explant sources for transformation. Seeds of RP-1 tobacco were germinated in vitro and were cut from the resulting plants using a $6 \mathrm{~mm}$ diameter punch. The disks were placed with the abaxial face side up on cocultivation Murashige-Skoog (MS) medium (MS salts, myo-inositol, $30 \mathrm{~g}$ of sucrose per liter, $1 \mathrm{mg}$ of benzylaminopurine per liter, and $6.0 \mathrm{~g}$ of agar per liter). Agrobacterium tumefaciens EHA105 carrying $r p f F$ pCambia2301 was used for transformation as described by
Caserta et al. (2014). The plates were kept at $24^{\circ} \mathrm{C}$ for 3 days, in the dark for the cocultivation period, and were then transferred to plates of MS selection medium (MS cocultivation with, per liter, $100 \mathrm{mg}$ of kanamycin and $500 \mathrm{mg}$ of cefotaxim). The plates were maintained under light (16-h light and 8-h dark cycle using cool white fluorescent lights $\left[75 \mu \mathrm{mol} \mathrm{s}^{-1} \mathrm{~m}^{-2}\right]$ ) until the development of shoots. Shoots were excised from the leaf disks and were evaluated for GUS activity, as described previously (Caserta et al. 2014). Leaves that became blue, indicative of GUS activity, were considered positive and were transferred to magenta boxes containing MS selection medium until they developed larger leaves and roots. Leaf disks from plants not infected with A. tumefaciens had no GUS activity.

Before transferring to the greenhouse, transgenic tobacco and citrus plants were analyzed by PCR, using total DNA as a template and specific primers for $r p f \mathrm{~F}$ to confirm the presence of the transgene. GUS- and PCR-positive tobacco events were transferred to the greenhouse, were self-pollinated, and seeds were collected and propagated for tests with the T1 generation. Similarly, only GUS- and PCR-positive citrus plants were grafted onto Carrizo rootstocks for further analysis.

The expression of $r p f F$ in positive plants was evaluated as described before (Caserta et al. 2014). For tobacco plants, the endogenous control was NtArpc3 (F: 5' CTGCAGAGGGTGA TTTTGCT 3' and R: 5' ATTGTGCATCACCAGCCATT 3'). Cyclophylin was used as the endogenous control for citrus plants (Cyc F 5'-AGAGTATGCAGAGGAATGG-3' and Cyc R 5'GTCCTTAACAGAAGTCCGT-3' primer), according to Boava et al. (2010).

The estimation of the transgene copy number was done according to Shepherd et al. (2009), by relative quantitation comparing the amplification of $r p f F$ to that of a control gene present in single copy in the genome of sweet orange, which encodes a lipid transfer protein (LTP) (NM_001288873) (Wu and Burns 2003). For this, two serial dilution curves were prepared from the DNA extracted from the transgenic lines. For each curve, a PCR was performed using specific primers for $r p f F$ and the LTP control (LTP F 5'-GCTGCCGCCAGAACCA-3' and LTP R 5' GCGGCTTGCTTCAAGCA-3') (Omar et al. 2008). The reactions were performed using the GoTaq qPCR master mix (Promega) and amplification conditions according to the 7500 System (Applied Biosystems). The estimated copy number was calculated as described by Shepherd et al. (2009), using the equation:

$$
\text { Ratio }=\frac{1+\text { Efficiency gene of interest }}{(\mathrm{Ct} \text { gene of interest })}
$$

Primer efficiencies were calculated using the MINER algorithm (Zhao and Fernald 2005).

\section{Challenge and evaluation}

of transgenic tobacco plants with $X$. fastidiosa.

All studies used $X$. fastidiosa $9 \mathrm{a} 5 \mathrm{c}$ cultivated for 7 days in periwinkle wilt solid medium at $28^{\circ} \mathrm{C}$. After growth, bacteria were suspended to an optical density at $600 \mathrm{~nm}=0.3$ (approximately $10^{8} \mathrm{CFU} / \mathrm{ml}$ ) in phosphate-buffered saline buffer. Ten transgenic lines were needle-inoculated with $X$. fastidiosa (Almeida et al. 2001) at the petiole of the first plant leaf. After three months, symptoms in transgenic leaves were compared with those developed in wild-type plants.

The five transgenic lines designated Nt_rpfF-1, Nt_rpfF-2, $\mathrm{Nt} \_r p f F-3, \mathrm{Nt} \_r p f F-4$, and $\mathrm{Nt} \_r p f F-5$ that exhibited reduced disease symptoms were selected and self-pollinated. Ten plants of each transgenic line were once again challenged with $X$. fastidios $a$ and, after three months, the incidence and severity of symptoms were evaluated by three different individuals. 
Disease incidence was calculated by the ratio of infected leaves and total number of leaves. Severity of symptoms was recorded by three different evaluators, following a scale previously determined according to the fractional leaf area damaged (score 1, up to $0.6 \%$ of damaged area; score 2 , up to $4.5 \%$; score 3 , up to $11 \%$; score 4 , up to $18 \%$; score 5 , up to $28 \%$; score 6 , up to $50 \%$; and score 7, more than 50\%). The data of incidence and severity from transgenic and wild-type plants were subjected to analysis of variance and were compared by $t$ test $(P<0.05)$, using the statistical program Assistat (Silva and Azevedo 2016).

\section{Challenge of transgenic citrus plants \\ with $X$. fastidios $a$ and evaluation of symptomatology.}

Ten buds of each transgenic sweet orange line and ten buds of wild-type control plants were grafted onto Citrus limonia Osbeck. In order to avoid chimeric plants, leaves of all grafted plants were screened for GUS activity as described above. Only positive plants were inoculated with $X$. fastidiosa as above. One month after inoculation, the presence of $X$. fastidiosa in inoculated plants was assessed, using PCR with primers RST31-F 5'-GCGTTAATTTTCGAAGTGATTCGATTGC-3' and RST33R 5'-CACCATTCGTATCCCGGTG-3' (Minsavage et al. 1994). The incidence and severity of symptoms caused by $X$. fastidiosa was assessed as for tobacco, with severity scored using a scale previously described (Amorin et al. 1993; Muranaka et al. 2013) and utilizing an image panel developed in this work (Supplementary Fig. S1).

Three evaluators analyzed incidence and severity at both nine and 18 months after inoculation. Symptom severity over the course of the study as a whole was calculated as AUDPC, using the trapezoidal integration method (Berger 1988) with the equation:

$$
\text { AUDPC }=(y i+y s) / 2 \times \mathrm{t},
$$

where $y i$ refers to average of scores given to symptoms at nine months, ys to average of scores given to symptoms at 18 months, and th the interval of time between both evaluations. Statistical analysis was done using $t$ test $(P<0.05)$.

\section{Evaluation of $X$. fastidiosa colonization along tobacco and citrus transgenic plants.}

At 14 weeks and 18 months after inoculation of tobacco and citrus plants, respectively, DNA extraction was performed, using petioles of leaves collected from different parts of the plants. Total DNA was collected from petioles collected at

Table 1. Primer sequences used for gene expression analysis

\begin{tabular}{|c|c|c|}
\hline LBI $^{\mathrm{a}}$ gene ID & Primer sequence $5^{\prime}-3^{\prime}$ & $\begin{array}{c}\text { Size of } \\
\text { amplicon (bp) }\end{array}$ \\
\hline \multirow[t]{2}{*}{ XF0910-petC } & F: GGGCTGCCATTCGTTGAA & \multirow[t]{2}{*}{110} \\
\hline & R: GGCACCGGTGACATTGAGA & \\
\hline \multirow[t]{2}{*}{ hxfB } & F: GCAAAACGAACGCTTACAAAC & \multirow[t]{2}{*}{102} \\
\hline & R: TCGGGGTTGAGGATTTCTTG & \\
\hline \multirow[t]{2}{*}{ XF1529-hsf } & F: CGGTGATAGCAATGATGTGG & \multirow[t]{2}{*}{105} \\
\hline & R: ATCGCTACCCACCTTCACAC & \\
\hline \multirow[t]{2}{*}{ XF0083-fimA } & F: AGCTCGTACACCGTTCACCAT & \multirow[t]{4}{*}{100} \\
\hline & R: CTGGGCCTGGCTCAAAATAG & \\
\hline \multirow[t]{2}{*}{ XF2370-gumB } & F: TTACCGTGACTGGTGCAGTG & \\
\hline & R: AGACTCGCCAGCGTGTTTAT & \\
\hline \multirow[t]{2}{*}{ XF0372-pilP } & F: GTATTCTGCGCAGGGAATGC & \multirow[t]{2}{*}{106} \\
\hline & R: TTCCAGCGGCTCCTTACGT & \\
\hline \multirow[t]{2}{*}{ XF2546-pils } & F: TGCCGAATCGTTGACTTTGTT & \multirow[t]{2}{*}{102} \\
\hline & R: GAGCTGCGATGCATGTTTGA & \\
\hline \multirow[t]{2}{*}{ XF1516-xadA1 } & F: TCATTCAGGCGTACGAAATCG & \multirow[t]{2}{*}{102} \\
\hline & R: CGTGACCATCGCAGGACTTT & \\
\hline
\end{tabular}

${ }^{\mathrm{a}} \mathrm{LBI}=$ Laboratory for Bioinformatics-UNICAMP. different distances from the inoculation point, to determine the extent of bacterial colonization. Samples were weighed and were then ground in liquid nitrogen and DNA was extracted using the DNeasy Blood and Tissue kit (Qiagen). Bacterial population size was determined by $\mathrm{qPCR}$, comparing to a standard curve developed for $X$. fastidiosa (Oliveira et al. 2002). DNA amplification was performed in a total volume of $13 \mu \mathrm{l}$ with $6.5 \mu \mathrm{l}$ of TaqMan PCR master mix (Applied Biosystems), $525 \mathrm{nM}$ of primers CVC-1 (TGA AGA TCA TGC AAA AAA CAA) and CCSM-1 (GCGCATGCCAAGTCCATATTT), $1.5 \mu \mathrm{l}$ of Probe TAQ-CVC-(6FAM) 5' AACCGCAGCAGAAGCCGCTCATC (TAMRA)-3' (Applied Biosystems), and 150 ng of DNA sample. Capture and signal amplification was performed in triplicate, using an ABI PRISM 7500 sequence detector system (Applied Biosystems). A linear regression was performed to correlate the $\mathrm{Ct}$ (threshold cycle) values obtained with DNA concentrations. To evaluate the bacterial population size in tobacco plants, a standard curve was established, using known concentrations of $X$. fastidiosa DNA diluted in plant DNA, as described by Oliveira et al. (2002). A linear regression was used to correlate the $\mathrm{Ct}$ values obtained with DNA concentrations used at each point of the curve. The standard curve obtained $[y=-3.0153 x$ (number of DNA copies $)+36.38]$ was linear (correlation coefficient $=$ $0.9901)$. For citrus plants, the standard curve obtained $[y=$ $-3.6023 x$ (number of DNA copies) + 39.252] was also linear (correlation coefficient $=0.9988)$. All statistical analyses were performed using Tukey's test $(P<0.05)$.

\section{Expression of genes responsive to DSF}

in $X$. fastidiosa isolated from transgenic citrus plants.

In order to assess expression of DSF-modulated genes in $X$. fastidiosa inoculated into transgenic plants, four petioles were sampled from transgenic $r p f F$-containing Hamlin and Pineapple sweet orange and were ground in liquid nitrogen. The samples were used for RNA extraction with the RNeasy plant mini kit (Qiagen). A total of $500 \mathrm{ng}$ of purified RNA was used for the synthesis of cDNA, using a reverse transcription system kit (Promega). Expression of genes related to movement (pilP and pilS) and biofilm formation ( $h x f B, h s f, x a d A 1$, fimA, gumB) were evaluated, using pet $C$ as an endogenous control (Table 1). qRT-PCR was performed using GoTaq qPCR master mix (Promega) in an ABI PRISM 7500 sequence detection system (Applied Biosystems). At the end of each run, a melting curve was conducted to confirm that the $\mathrm{Ct}$ values were associated with a single PCR product. Relative expression quantification was calculated from the $\mathrm{Ct}$ values, as by Livak and Schmittgen (2001). Two experiments, each with two internal replicates were performed for each treatment.

\section{ACKNOWLEDGMENTS}

We thank F. de A. A. Mourão-Filho and L. C. L. Stipp from Escola Superior de Agricultura "Luiz de Queiroz"/Universidade de São Paulo for assistance in citrus transformation; L. F. C. da Silva from Centro de Citricultura "Sylvio Moreira"-IAC for greenhouse plant propagation. This work was supported by research grants from Fundação de Amparo à Pesquisa do Estado de São Paulo (FAPESP -2013/10957-0) and Conselho Nacional de Desenvolvimento Científico e Tecnológico (CNPq-INCTCitros 08/57909-2, 573848/08-4). R. Caserta was a fellow Ph.D. from FAPESP (2009/50253-7), M. A. Takita and A. A. De Souza are recipients of research fellowships from CNPq.

\section{LITERATURE CITED}

Almeida, R. P. P., Pereira, E. F., Purcell, A. P., and Lopes, J. R. S. 2001. Multiplication and movement of a citrus strain of Xylella fastidiosa within sweet orange. Plant Dis. 85:382-386.

Amorin, L., Bergamin, F. A., Palazzo, D. A., Bassanezi, R. B., Godoy, C. V., and Torres, G. A. M. 1993. Citrus variegation chlorosis: A diagramatic scale for the evaluation of the severity of the disease. Fitopatol. Bras. 18:174-180. 
Beaulieu, E. D., Ionescu, M., Chatterjee, S., Yokota, K., Trauner, D., and Lindow, S. 2013. Characterization of a diffusible signaling factor from Xylella fastidiosa. MBio 4:e00539-e12.

Berger, R. D. 1988. The analysis of the effects of control measures on the development of epidemics. p. 137-151. In: Experimental Techniques in Plant Disease Epidemiology. J. Kranz and J. Rotem, eds. Springer, Berlin.

Boava, L. P., Laia, M. L., Jacob, T. R., Dabbas, K. M., Gonçalves, J. F., Ferro, J. A., Ferro, M. I. T., and Furtado, E. L. 2010. Selection of endogenous genes for gene expression studies in Eucalyptus under biotic (Puccinia psidii) and abiotic (acibenzolar-S-methyl) stresses using RTqPCR. BMC Res. Notes 3:43.

Bourras, S., Rouxel, T., and Meyer, M. 2015. Agrobacterium tumefaciens gene transfer: How a plant pathogen hacks the nuclei of plant and nonplant organisms. Phytopathology 10:1288-1301.

Caserta, R., Picchi, S. C., Takita, M. A., Tomaz, J. P., Pereira, W. E. L., Machado, M. A., Ionescu, M., Lindow, S., and De Souza, A. A. 2014. Expression of Xylella fastidiosa RpfF in citrus disrupts signaling in Xanthomonas citri subsp. citri and thereby its virulence. Mol. PlantMicrobe Interact 27:1241-1252.

Chatterjee, S., Almeida, R. P. P., and Lindow, S. 2008. Living in two worlds: The plant and insect lifestyles of Xylella fastidiosa. Annu. Rev. Phytopathol. 46:243-271.

Gelvin, S. B. 2010. Finding a way to the nucleus. Curr. Opin. Microbiol. 13: 53-58.

Guilhabert, M. R., and Kirkpatrick, B. C. 2005. Identification of Xylella fastidiosa antivirulence genes: Hemagglutinin adhesins contribute to $X$. fastidiosa biofilm maturation and colonization and attenuate virulence. Mol. Plant-Microbe Interact 18:856-868.

Guo, Y., Zhang, Y., Li, J. L., and Wang, N. 2012. Diffusible signal factormediated quorum sensing plays a central role in coordinating gene expression of Xanthomonas citri subsp. citri. Mol. Plant-Microbe Interact 25:165-179.

Helman, Y., and Chernin, L. 2015. Silencing the mob: Disrupting quorum sensing as a means to fight plant disease. Mol. Plant Pathol. 16:316-329.

Hopkins, D. L., and Purcell, A. H. 2002. Xylella fastidiosa: Cause of Pierce's disease of grapevine and other emergent diseases. Plant Dis. 86:1056-1066.

Ionescu, M., Baccari, C., Da Silva, A. M., Garcia, A., Yokota, K., and Lindow, S. E. 2013. Diffusible signal factor (DSF) synthase RpfF of Xylella fastidiosa is a multifunction protein also required for response to DSF. J. Bacteriol. 195:5273-5284.

Ionescu, M., Yokota, K., Antonova, E., Garcia, A., Beaulieu, E., Hayes, T., Iavarone, A. T., and Lindow, S. E. 2016. Promiscuous diffusible signal factor production and responsiveness of the Xylella fastidiosa Rpf system. mBio 7:e01054-16.

Kakkar, A., Nizampatnam, N. R., Kondreddy, A., Pradhan, B. B., and Chatterjee, S. 2015. Xanthomonas campestris cell-cell signalling molecule DSF (diffusible signal factor) elicits innate immunity in plants and is suppressed by the exopolysaccharide xanthan. J. Exp. Bot. 66: 6697-6714.

Kaplan, H. B., and Greenberg, E. P. 1985. Diffusion of autoinducer is involved in regulation of the Vibrio fischeri luminescence system. J. Bacteriol. 163:1210-1214.

Krysan, P. J., Young, J. C., Jester, P. J., Monson, S., Copenhaver, G., Preuss, D., and Sussman, M. R. 2002. Characterization of T-DNA insertion sites in Arabidopsis thaliana and the implications for saturation mutagenesis. OMICS 6:163-174.

Lindow, S., Newman, K., Chatterjee, S., Baccari, C., Lavarone, A. T., and Ionescu, M. 2014. Production of Xylella fastidiosa diffusible signal factor in transgenic grape causes pathogen confusion and reduction in severity of Pierce's disease. Mol. Plant-Microbe Interact 27:244-254.

Livak, K. J., and Schmittgen, T. D. 2001. Analysis of relative gene expression data using real-time quantitative PCR and the $2^{-\Delta \Lambda C(T)}$ method. Methods 25:402-408.

Lopes, S. A., Ribeiro, D. M., Roberto, P. G., and França, S. C. 2000. Nicotiana tabacum as an experimental host for the study of plant-Xylella fastidiosa interactions. Plant Dis. 84:827-830.

Machado, E. C., Quaggio, J. A., Lagôa, A. M. M. A., Ticelli, M., and Furlani, P. R. 1994. Trocas gasosas e relações hídricas em laranjeiras com clorose variegada dos citros. Rev. Bras. Fisiol. Vegetal 6:53-57.

Merfa, M. V., Niza, B., Takita, M. A., and De Souza, A. A. 2016. The MqsRA toxin-antitoxin system from Xylella fastidiosa plays a key role in bacterial fitness, pathogenicity, and persister cell formation. Front. Microbiol. 7:904.

Minsavage, G. V., Thompson, C. M., Hopkins, D. L., Leite, R. M. V. B. C. and Stall, R. E. 1994. Development of a polymerase chain reaction protocol for detection of Xylella fastidiosa in plant tissue. Phytopathology 84:456-461.
Muranaka, L. S., Giorgiano, T. E., Takita, M. A., Forim, M. R., Silva, L. F. C., Coletta-Filho, H. D., Machado, M. A., and de Souza, A. A. 2013. N-acetylcysteine in agriculture, a novel use for an old molecule: Focus on controlling the plant-pathogen Xylella fastidiosa. PLoS One 8: e72937.

Newman, K. L., Almeida, R. P. P., Purcell, A. H., and Lindow, S. E. 2004. Cell-cell signaling controls Xylella fastidiosa interactions with both insects and plants. Proc. Natl. Acad. Sci. U.S.A. 101:1737-1742.

Oliveira, A. C., Vallim, M. A., Semighini, C. P., Araújo, W. L., Goldman, G. H., and Machado, M. A. 2002. Quantification of Xylella fastidiosa from citrus trees by real-time polymerase chain reaction assay. Phytopathology 92:1048-1054.

Omar, A. A., Dekkers, M. G. H., Graham, J. H., and Grosser, J. W. 2008. Estimation of transgene copy number in transformed citrus plants by quantitative multiplex real-time PCR. Biotechnol. Prog. 24:1241-1248.

Park, S. Y., Kang, H. O., Jang, H. S., Lee, J. K., Koo, B. T., and Yum, D. Y. 2005. Identification of extracellular $N$-acylhomoserine lactone acylase from a Streptomyces sp. and its application to quorum quenching. Appl. Environ. Microbiol. 71:2632-2641.

Radhamony, R. N., Prasad, A. M., and Srinivasan, R. 2005. T-DNA insertional mutagenesis in Arabidopsis: A tool for functional genomics. Electron. J. Biotechnol. 8:82-106.

Saponari, M., Boscia, D., Nigro, F., and Martelli, G. P. 2013. Identification of DNA sequences related to Xylella fastidiosa in oleander, almond and olive trees exhibiting leaf scorch symptoms in Apulia (Southern Italy). J. Plant Pathol. 95:3.

Schenk, S. T., Hernández-Reyes, C., Samans, B., Stein, E., Neumann, C., Schikora, M., Reichelt, M., Mithöfer, A., Becker, A., Kogel, K. H., and Schikora, A. 2014. N-Acylhomoserine lactone primes plants for cell wall reinforcement and induces resistance to bacterial pathogens via the salicylic acid/oxylipin pathway. Plant Cell 26:2708-2723.

Schikora, A., Schenk, S. T., Stein, E., Molitor, A., Zuccaro, A., and Kogel, K. H. 2011. N-acyl-homoserine lactone confers resistance toward biotrophic and hemibiotrophic pathogens via altered activation of AtMPK6. Plant Physiol. 157:1407-1418.

Schnell, J., Steele, M., Bean, J., Neuspiel, M., Girard, C., Dormann, N., Pearson, C., Savoie, A., Bourbonnière, L., and Macdonald, P. 2015. A comparative analysis of insertional effects in genetically engineered plants: Considerations for pre-market assessments. Transgenic Res. 24:1-17.

Shepherd, C. T., Moran Lauter, A. N., and Scott, M. P. 2009. Determination of transgene copy number by real-time quantitative PCR. Methods Mol. Biol. 526:129-134.

Silva, F. A. S., and Azevedo, C. A. V. 2016. The Assistat software version 7.7 and its use in the analysis of experimental data. Afr. J. Agric. Res. 11: 3733-3740.

Simpson, A. J. G., Reinach, F. C., Arruda, P., Abreu, F. A., Acencio, M., Alvarenga, R., Alves, L. M., Araya, J. E., Baia, G. S., Baptista, C. S., Barros, M. H., Bonaccorsi, E. D., Bordin, S., Bové, J. M., Briones, M. R., Bueno, M. R., Camargo, A. A., Camargo, L. E., Carraro, D. M., Carrer, H., Colauto, N. B., Colombo, C., Costa, F. F., Costa, M. C., Costa-Neto, C. M., Coutinho, L. L., Cristofani, M., Dias-Neto, E., Docena, C., El-Dorry, H., Facincani, A. P., Ferreira, A. J., Ferreira, V. C., Ferro, J. A., Fraga, J. S., França, S. C., Franco, M. C., Frohme, M., Furlan, L. R., Garnier, M., Goldman, G. H., Goldman, M. H., Gomes, S. L., Gruber, A., Ho, P. L., Hoheisel, J. D., Junqueira, M. L., Kemper, E. L., Kitajima, J. P., Krieger, J. E., Kuramae, E. E., Laigret, F., Lambais, M. R., Leite, L. C., Lemos, E. G., Lemos, M. V., Lopes, S. A., Lopes, C. R., Machado, J. A., Machado, M. A., Madeira, A. M., Madeira, H. M., Marino, C. L., Marques, M. V., Martins, E. A., Martins, E. M., Matsukuma, A. Y., Menck, C. F., Miracca, E. C., Miyaki, C. Y., Monteriro-Vitorello, C. B., Moon, D. H., Nagai, M. A., Nascimento, A. L., Netto, L. E., Nhani, A., Jr., Nobrega, F. G., Nunes, L. R., Oliveira, M. A., de Oliveira, M. C., de Oliveira, R. C., Palmieri, D. A., Paris, A., Peixoto, B. R., Pereira, G. A., Pereira, H. A., Jr., Pesquero, J. B., Quaggio, R. B., Roberto, P. G., Rodrigues, V., de M Rosa, A. J., de Rosa, V. E., Jr., de Sá, R. G., Santelli, R. V., Sawasaki, H. E., da Silva, A. C., da Silva, A. M., da Silva, F. R., da Silva, W. A., Jr., da Silveira, J. F., Silvestri, M. L., Siqueira, W. J., de Souza, A. A., de Souza, A. P., Terenzi, M. F., Truffi, D., Tsai, S. M., Tsuhako, M. H., Vallada, H., Van Sluys, M. A., Verjovski-Almeida, S., Vettore, A. L., Zago, M. A., Zatz, M., Meidanis, J., and Setubal, J. C. 2000. The genome sequence of the plant pathogen Xylella fastidiosa. Nature 406:151-157.

Sun, Q., Sun, Y., Walker, M. A., and Labavitch, J. M. 2013. Vascular occlusions in grapevines with Pierce's disease make disease symptom development worse. [OA] Plant Physiol. 161:1529-1541.

Van Sluys, M. A., de Oliveira, M. C., Monteiro-Vitorello, C. B., Miyaki, C. Y., Furlan, L. R., Camargo, L. E., da Silva, A. C., Moon, D. H., Takita, M. A., 
Lemos, E. G., Machado, M. A., Ferro, M. I., da Silva, F. R., Goldman, M. H., Goldman, G. H., Lemos, M. V., El-Dorry, H., Tsai, S. M., Carrer, H., Carraro, D. M., de Oliveira, R. C., Nunes, L. R., Siqueira, W. J., Coutinho, L. L., Kimura, E. T., Ferro, E. S., Harakava, R., Kuramae, E. E., Marino, C. L., Giglioti, E., Abreu, I. L., Alves, L. M., do Amaral, A. M., Baia, G. S., Blanco, S. R., Brito, M. S., Cannavan, F. S., Celestino, A. V., da Cunha, A. F., Fenille, R. C., Ferro, J. A., Formighieri, E. F., Kishi, L. T., Leoni, S. G., Oliveira, A. R., Rosa, V. E., Jr., Sassaki, F. T., Sena, J. A., de Souza, A. A., Truffi, D., Tsukumo, F., Yanai, G. M., Zaros, L. G., Civerolo, E. L., Simpson, A. J., Almeida, N. F., Jr., Setubal, J. C., and Kitajima, J. P. 2003. Comparative analyses of the complete genome sequences of Pierce's disease and citrus variegated chlorosis strains of Xylella fastidiosa. J. Bacteriol. 185:1018-1026.
Wang, N., Li, J. L., and Lindow, S. E. 2012. RpfF-dependent regulon of Xylella fastidiosa. Phytopathology 102:1045-1053.

Wu, Z., and Burns, J. K. 2003. Isolation and characterization of a cDNA encoding a lipid transfer protein expressed in 'Valencia' orange during abscission. J. Exp. Bot. 54:1183-1191.

Zhao, S., and Fernald, R. D. 2005. Comprehensive algorithm for quantitative real-time polymerase chain reaction. J. Comput. Biol. 12: 1047-1064.

\section{AUTHOR-RECOMMENDED INTERNET RESOURCE}

Laboratory for Bioinformatics-UNICAMP Xylella fastidiosa Genome Project: http://aeg.lbi.ic.unicamp.br/xf 